ljtihad: Jurnal Wacana Hukum Islam dan Kemanusiaan Vol. 19, No. 1 (2019), pp. 1-25, doi : 10.18326/ijtihad.v19i1.1-25

\title{
Paradigma fikih baru Jamal al-Banna dan relevansinya terhadap pembaruan peran perempuan dalam hukum keluarga Islam (Fiqụ al-Munākaḥāt)
}

\author{
Syaiful Bahri
}

Fakultas Syariah IAIN Kediri

E-mail: saiful.madura@gmail.com

DOI: 10.18326/ijtihad.v19i1.1-25

The role of women, according to classical fiqh (Islamic law) literature, especially figh al-Munäkahät (Islamic family law), tends to be regarded as a complementary part of domestic life. Their role is limited to the domestic territory, and restrain to play a public role. This paper tries to reconstruct the role of women in Islamic family law, utilizing the new figh paradigm initiated by Jamal al-Banna. To answer this problem, the author conducted a literature study by examining two works of Jamal: Naḥwa Fighin Jadid and Al-Mar'ah al-Muslimah bayna Taḩrir Al-Qur'an wa Taqyid al-Fuqahä.' This paper concludes that some issues regarding the role of women in Islamic family law need renewal. There are four crucial issues that are reviewed using the new figh paradigm of Jamal al-Banna, namely the minimum age of marriage, wali's ijbār rights, polygamy, and divorce.

Persoalan peran perempuan dalam literatur fikih klasik, khususnya dalam figh al-Munākahāat, cenderung dianggap sebagai pelengkap saja dalam kehidupan rumah tangga. Peran mereka hanya dibatasi dalam wilyah domestik, dikekang untuk berperan di ranah publik. Tulisan ini akan mencoba untuk merekonstruksi peran perempuan dalam hukum keluarga Islam (fiqh al-Munäkahăàt), dengan menggunakan paradigma fikih baru yang digagas Jamal al-Banna. Untuk menjawab persoalan itu, penulis melakukan studi kepustakaan dengan mengkaji dua karya Jamal: Naḥwa Fiqhin Jadid and AlMar'ah al-Muslimah bayna Taḥrir Al-Qur'ān wa Taqvid al-Fuqabä.' Tulisan ini menghasilkan kesimpulan bahwa beberapa isu peran perempuan dalam hukum keluarga Islam memang perlu dilakukan pembaruan. Ada empat isu krusial yang ditinjau ulang menggunakan paradigma fikih baru Jamal alBanna, yaitu batas minimal usia perkawinan, hak jjbär wali, poligami, dan talak.

Keywords: The Role of Women; Jamal al-Banna; Islamic Family Law. 
ljtihad: Jurnal Wacana Hukum Islam dan Kemanusiaan, Volume 19, No. 1, Juni 2019: 1-25

\section{Pendahuluan}

Dalam kehidupan masyarakat muslim, fikih menempati posisi yang sangat signifikan. Fikih menjadi rujukan fundamental dalam menjawab persoalan yang terjadi, baik yang berhubungan dengan dimensi vertikal ('ibädah) maupun horizontal (mu'àmalah). Secara etemologis, kata fikih berasal dari bahasa Arab al-Fiqh yang bermakna pemahaman (alFahmu) (Tamhaz, 2009 I: 16). Sedang secara terminologis, fikih bermakna ilmu tentang hukum syara' yang bersifat praktis, diambil dari dalil-dalinya yang terperinci. (Zuhaili, 2013 I: 29).

Begitu pentingnya fikih dalam kehidupan masyarakat muslim, menjadikan disiplin keilmuan ini sebagai salah satu disiplin ilmu yang selalu menarik untuk dikaji dan didiskusikan. Salah satu produk pemikiran dalam fikih adalah persoalan keluarga yang biasanya disebut dengan beberapa istilah, di antaranya: Fiqh Munäkahăt, Aḥwāl al-Syakhsìyah, dan Nizām al-Usrah,dan hukum keluarga Islam. Dari istilah-istilah tersebut dapat dipahami bahwa yang dibahas dalam fikih keluarga adalah hal-hal yang berhubungan dengan perkawinan. (Syarifuddin, 2006: 5).

Persoalan keluarga dan perkawinan merupakan persoalan yang selalu menarik untuk diperbincangkan. Ketentuan-ketentuan yang ada dalam pelbagai literatur hukum keluarga Islam klasik, oleh sebagian kalangan sudah dianggap tidak relevan dengan perkembangan zaman. Tema yang biasanya sering didiskusikan adalah soal relasi suami isteri, poligami, dan batasan usia perkawinan. Apa yang dirumuskan dalam literatur hukum keluarga Islam klasik tentang tema-tema tersebut, oleh sebagian kalangan dianggap sudah tidak relevan dan perlu dilakukan pembaruan.

Salah satu intelektual Muslim yang getol menyuarakan pembaruan dalam hukum Islam, termasuk di dalamnya persoalan hukum keluarga, adalah Jamal al-Banna (selanjutnya disebut Jamal). Jamal adalah adik kandung pendiri Ikhwanul Muslimin, Hasan al-Banna. Meski bersaudara, pemikiran Jamal sangat berbeda dengan pemikiran kakak kandungnya (al-Banna, 1994: 4). Dalam buku al-Mar'ah al-Muslimah bayna tạ̣rir al-Qur'ān wa Taqüd alFuqaha', Jamal menyuarakan pembaruan terhadap isu-isu perempuan, khususnya dalam wilayah keluarga. Jamal juga mengkritik pemikiran fuqahā yang melakukan pembatasan, padahal al-Qur'an justru membebaskan. 
Atas dasar itu, tulisan ini akan mendiskusikan paradigma pemikiran fikih baru Jamal, sekaligus melihat relevansi pemikiran tersebut terhadap peran perempuan dalam hukum keluarga Islam. Untuk itu, penulis akan melakukan studi kepustakaan dengan mengkaji secara kritis karya-karya Jamal, terutama yang membahas perempuan dan hukum keluarga. Setelah mengkaji pemikiran Jamal, penulis akan merelevansikan pemikiran tersebut terhadap isu-isu pembaruan peran perempuan dalam hukum keluarga Islam.

\section{Historisitas hukum keluarga Islam}

Hukum keluarga Islam (Fiqh Munäkahăt atau Aḅwäl al-Syakhsiyah)merupakan bagian dari kajian ilmu fikih. Secara garis besar, dimensi kajian dalam fikih dapat diklasifikasikan menjadi dua: ibadah dan muamalah. Ibadah membahas aspek-aspek praktis hubungan antara manusia dengan Tuhan, seperti salat, zakat, puasa, dan haji (Ahmad, 2018: 189). Sedang muamalah membahas hubungan antar sesama manusia dalam pelbagai dimensinya, baik dalam ranah politik (siyāsah), keluarga (munäkahăàt, aḥwäl al-Syakhsịyah), pidana (jināyah), ekonomi (māliyah iqtișādiyah) (Zaidan, 1976: 156).

Sebagai bagian dari disiplin keilmuan fikih, hukum keluarga Islam dapat dipahami sebagai produk pemikiran yang bersifat historis. Fikih, pada hakikatnya adalah produk historis yang lahir dari kognisi seorang faqỉ (Auda, 2015: 86). Fikih dihasilkan dari pemikiran manusia yang terbatas, dan bukan 'pengetahuan ilahiah' yang dijamin kebenarannya (Taimiyah, tt. XIX: 131).

Selain itu, pada dasarnya, fikih lahir dari tiga komponen penting: wahyu, realitas atau konteks, serta orang yang melahirkan fikih tersebut (al-Faqih). Ketiga komponen tersebut merupakan unsur utama yang membentuk lahirnya fikih. Sehingga, antara ketiganya tidak dapat dipisahkan. Wahyu sendiri bersifat normatif, otoritas dan kebenarannya terjamin sebab ia lahir dari Tuhan yang Maha Suci. Sedang realitas terus berkembang sejalan dengan perkembangan zaman. Adapun pemikiran manusia bersifat relatif, kebenarannya berada pada level 'mungkin', dan tidak pasti sebagaimana wahyu (al-Raisuni, 2013: 11).

Jika fikih secara umum bersifat historis, maka hukum keluarga yang tidak lain adalah bagian dari fikih itu sendiri, secara otomatis juga bersifat historis. Karena bersifat historis, maka tema-tema yang ada di dalamnya, pada prinsipnya menerima kritik dan perdebatan. 
ljtihad: Jurnal Wacana Hukum Islam dan Kemanusiaan, Volume 19, No. 1, Juni 2019: 1-25

Artinya, persoalan-persoalan yang dibahas dalam hukum keluarga dapat saja dilakukan pembaruan (tajdid) dan tinjauan ulang (muräja'ah).

Dengan demikian, tema-tema penting dalam hukum keluarga, yang masih relevan dapat dipertahankan. Sedang yang tidak relevan, dapat diperbarui disesuaikan dengan kebutuhan dan perkembangan zaman. Membahas historisitas fikih sangat penting sebab, banyak kalangan yang menganggap bahwa fikih merupakan produk sakral yang tidak dapat dikritik apalagi diperbarui. Jika hal ini dibiarkan, maka yang terjadi adalah upaya sakralisasi terhadap hasil pemikiran keagamaan (taqdis al-Afkär al-Diniyah) (Meuleman, 2012: 9). Padahal, antara agama dan pemikiran keagamaan merupakan dua entitas yang berbeda.

\section{Jamal al-Banna: sebuah biografi intelektual}

Jamal al-Banna merupakan sosok pemikir besar kontemporer dalam dunia Islam. Dia lahir dari keluarga dengan tradisi intelektual yang kuat. Kakaknya, Hasan al-Banna, merupakan pendiri dan tokoh besar organisasi berideologi Islam di Mesir, al-Ikhwān alMuslimūn (Nasution, 1992: 304). Status Jamal sebagai adik kandung Hasan al-Banna turut berpengaruh terhadap posisinya dalam kancah pemikiran Islam kontemporer. Meski bersaudara, pemikiran keduanya dapat dikatakan sangat berbeda. Bahkan, Jamal tidak segan mengkritik pemikiran kakak kandungnya tersebut.

Jamal al-Banna bernama lengkap Ahmad Jamaluddin Ahmad Abdurrahman al-Banna. Lahir pada bulan Desember tahun 1920 di al-Mahmudiyah, sebuah daerah yang masuk dalam teritori Provensi al-Bakhirah, Mesir. Jamal lahir dari pasangan ayah bernama Ahmad bin Abdurrahman bin Muhammad as-Sa'ti dan dari ibu bernama Ummu Sa'ad Shaqar (Zamzami, 2008: 18). Ayah Jamal merupakan tokoh intelektual dengan karya monumental berjudul, al-Fath ar-Rabbani fi Tartỉb al-Musnad al-Imām ạ̣mad ibn Hanbal al-Syaibāni, berjumlah 24 jilid.

Pengembaraan intelektual Jamal secara formal dimulai dari Madrasah Ibtidaiyah dan

Madrasah Tsanawiyah Khadawiyah, salah satu sekolah favorit di Kairo pada saat itu. Jenjang pendidikan formal yang ditempuh Jamal dapat dikatakan tidak berjalan mulus. Karena ada masalah dengan pengajar bahasa Inggrisnya, Jamal harus mengakhiri pendidikan dasar formalnya sampai pada tingkat satu saja. Kemudian, atas desakan keluaganya, Jamal melanjutkan pendidikan ke sekolah perdagangan selama tiga tahun. 
Paradigma fikih baru Jamal al-Banna dan relevansinya terhadap pembaruan ...(Syaiful Bahri)

Meski gagal dalam pendidikan formal, namun tidak berarti Jamal berhenti belajar. Dia menekuni dua aktivitas yang menjadi kesenangannya, yakni membaca dan menulis. Membaca dan menulis, bagi Jamal, merupakan obat di tengah ketidakpercayaannya pada pendidikan formal yang saat itu ada di Mesir. Jamal lebih sering menghabiskan waktu di perpustakaan daripada tempat lain. Atas kebisaan inilah, sampai akhir hayatnya, Jamal dikenal sebagai intelektual Muslim yang produktif melahirkan banyak karya dalam pelbagai dispilin keilmuan.

Pengaruh dari kondisi keluarga sangat berpengaruh terhadap cara berpikir Jamal di kemudian hari. Ayahnya, yang tidak lain merupakan intelektual terkemuka, memberikan kebebasan kepada anak-anaknya untuk membaca dan mempelajari apapun. Kebebasan yang menjadi budaya dalam keluarga turut serta dalam membentuk kepribadian Jamal untuk biasa berbeda dengan siapapun, termasuk dengan keluarganya sendiri (Zamzami, 2008: 22-23).

Jamal tumbuh menjadi pemikir besar dengan gagasan-gagasan baru yang kontroversial. Umumnya, pemikiran Jamal berisi gagasan-gagasan yang mendobrak pemahaman yang sudah menjadi status quo di masyarakat. Dengan keyakinan serta keteguhannya dalam memegang prinsip, Jamal seakan tidak peduli jika gagasan yang dikembangkannya akan menuai kontroversi dan kritik dari sana-sini.

Rabu, 30 Januari 2013, intelektual besar Mesir itu meninggal dunia akibat penyakit radang paru-paru yang dideritanya (Faiz, 2015: 60). Sebagai seorang intelektual yang mempunyai hobi membaca dan menulis, Jamal meninggalkan banyak karya, di antaranya: dimaqrätiyah

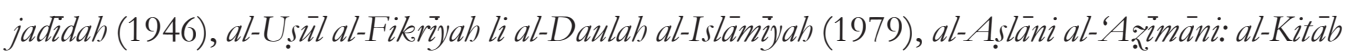
wa al-Sunnah 'ra'yu jadidah' (1982), al-Islām huwa al-Ḥ̂al (1988), Kallā Șumma Kallā: Kallā li Fuqahä' al-Taqlid Kallā li Du'äti al-Tanwìr (1995), Naḥw Fiqhin Jadid (1995-1999), al-Mar'ah al-Muslimah bayna tahrir al-Qur'än wa taqyid al-Fuqahä' (1998), ma ba'da al-Ikhwän al-Muslimin? (1995), isträtijiyah al-Da'wah al-Isläm fi al-Qur'an fi al-Qarn 21 (2000), tatwir al-Qur'an (2001), al-Hịjāb (2002), al-Islām din wa al-Ummah wa laisa dinan wa daulatan (2003).

\section{Jamal al-Banna dan gagasan fikih baru dalam Islam}

Jamal dikenal sebagai intelektual dan pemikir yang lingkup kajiannya mencakup banyak dimensi dalam Islam, termasuk di dalamnya persoalan fikih. Karya Jamal, nạ̣wa fiqhin jadid, 
ljtihad: Jurnal Wacana Hukum Islam dan Kemanusiaan, Volume 19, No. 1, Juni 2019: 1-25

dapat disebut sebagai magnum opus yang membahas tentang gagasan fikih baru dalam Islam. Terbagi dalam tiga terbitan, nạ̣wa fiqhin jadid ditulis Jamal dalam kurun waktu 1995-1999.

Secara garis besar, buku nạ̣wa fiqhin jadid berisi kritik tajam terhadap pemikiranpemikiran fuqahä' klasik yang cenderung konservatif dan tekstualis. Selain mengkritisi pemikiran fuqahä, Jamal juga mengkritik pemikir-pemikir kontemporer semacam, Syahrur, Arkoun, Nasr Hamid Abu Zaid. (huseinmuhammad.net). Kritik yang disampaikan Jamal bukan kepada ide pembaruan yang digagas, melainkan kepada metode yang digunakan. Telah maklum, meski sama-sama mengususng ide pembaruan, tidak jarang antara satu tokoh pembaharu dengan tokoh lainnya, terjadi saling kritik tajam atas ide yang diusung. Selain Jamal, saling kritik juga pernah terjadi antara Hasan Hanafi dan Abed al-Jabiri (Hanafi dan al-Jabiri, 1990).

Fondasi berpikir fikih baru yang digagas Jamal dibahas dalam buku pertama nạ̣wa fiqhin jadid. Dalam bab pertama buku tersebut, Jamal memberi judul muntaliqāt wa mafähim, kurang lebih jika diartikan dalam bahasa Indonesia menjadi 'titik tolak dan pemahamanpemahaman. Ada empat pasal yang dibahas Jamal dalam bab tersebut. Keempat pasal tersebut menjadi titik tolak fikih baru yang digagas Jamal.

Jamal memulai kajiannya dengan membahas salah satu isu dasar dalam hukum Islam, yakni prinsip bahwa kebebasan adalah asal (al-Baräah al-Astiyah). Kebebasan, menurut Jamal, pemberlakuannya tidak terbatas pada persoalan halal-haram sebagaimana banyak ditemukan dalam kajian fikih. Kebebasan merupakan istilah penting dalam pemikiran Islam yang berhubungan dengan seluruh kehidupan manusia (al-Banna, 1995: 31). Berdasarkan prinsip ini, kebebasan merupakan harta berharga yang dilindungi dalam agama.

Atas dasar ini, memaksakan seseorang untuk tunduk dan menerima penafsiran tertentu dapat dikatakan mencederai prinsip kebebasan yang merupakan hak dasar yang dimiliki setiap individu. Cara berpikir demikian merupakan kritik terhadap fenomena pemapanan pemahaman yang akhir-akhir banyak terjadi. Adanya kelompok yang mengklaim kebenaran hanya dalam dirinya, sekaligus menolak kebenaran yang ada dalam kelompok lain, merupakan praktik yang mencederai kebebasan. Bahkan, lebih jauh lagi, ada kelompok yang memaksakan pemahamannya harus diterima. 
Prinsip al-Barāab al-A sliyah berimplikasi pada cara pandang Jamal terhadap konsep halal-haram dalam Islam. Bagi Jamal, keharaman yang sudah secara tegas diturunkan oleh Al-Qur'an maupun sunnah Nabi tidak ada keraguan untuk mentaatinya. Berbeda dengan keharaman yang diproduksi oleh fuqabā yang menurutnya kualitas keharamannya lebih rendah daripada yang ditegaskan oleh Al-Qur'an dan sunnah Nabi. Meski dianalogikan kepada kasus yang ada dalam nash, tetap tidak ada jaminan bahwa hasil analogi tersebut sudah terjamin kebenarannya (al-Banna, 1995: 33). Implikasinya, apabila keharaman tersebut lahir dari pemikiran manusia, maka pemberlakuannya tidak dapat dipaksakan kepada semua orang dalam pelbagai tempat.

Pandangan Jamal ini disandarkan pada pemahamannya bahwa prinsip al-Bara'ah al-A. sliyah merupakan dasar dalam pemikiran Islam. Bagi Jamal, berdasarkan prinsip al-Baráa ah al-Assiyah, segala sesuatu selain ibadah inti harus dihukumi boleh. Dalam konteks ini, Jamal sepertinya sejalan dengan prinsip yang dianut dalam salah satu kaidah fikih, al-Așlu $f i$ alAsyä al-Ibähạh, bahwa hukum asal segala sesuatu adalah boleh (al-Burnu, 1996: 191).

Jamal juga mengomentari keberadaan prinsip al-Barāabh al-A slizah yang tidak terlalu diperhatikan dalam kajian Ushul Fiqh. Sebagaimana yang sudah maklum, saat berbicara tentang dalil dalam Islam, maka yang menjadi acuan dasar adalah empat dalil saja, yakni Al-Qur'an, Sunnah, Ijma', dan Qiyas (al-Banna, 1995: 34). Dalam kajian ilmu Ushul Fiqh, keempat dalil tersebut biasanya disebut sebagai dalil yang disepakati, atau al-Adillah alMuttafaq 'Alaỉā (al-Bugha, tt.: 18).

Cara berpikir yang dipegang oleh Jamal dalam prinsip al-Barāáh al-Ạsliyah ini berimplikasi pada posisi prinsip kebebasan dalam Islam. Agar prinsip al-Barāáah al-A stizyah kembali menjadi prinsip utama, menurut Jamal perlu dilakukan rekonstruksi dengan cara menjadikan prinsip tersebut sebagai salah satu dalil penting di dalam ilmu Ushul Fiqh (alBanna, 1995: 36). Selain itu, dengan menjadikan al-Barāab al-A Asliyah sebagai prinsip, maka konsep halal-haram tidak lagi menjadi domain golongan tertentu, yang pemberlakuannya dapat dipaksakan kepada orang lain. Yang tidak dapat diganggu gugat hanyalah halalharam yang sudah digariskan secara tegas oleh nash. Sedang halal-haram yang diproduksi oleh pemikiran manusia, maka setiap individu mempunyai hak untuk menerima maupun menolaknya. 
Jamal juga membahas dan mengkitisi tiga terminologi dalam Islam yang biasanya sering dimaknai secara tumpang tindih, yaitu istilah akidah, syariah, dan fikih. Akidah merupakan salah satu dimensi penting dalam Islam yang dimaknai sebagai sesuatu yang diyakini dan dipegang teguh, diimani berdasarkan dalil-dalil yang sesuai dengan kenyataan, seperti yang terdapat dalam rukun iman yang enam (Audah, 2008: 116). Sedang syariah secara bahasa, dapat diartikan sebagai jalan yang lurus, atau al-Ṭariqah al-Mustaqimah (Ali, 2007: 79). Secara istilah, terdapat banyak definisi tentang syariah, salah satunya adalah semua aturan Allah yang ditetapkan bagi hamba-hambanya, baik menyangkut keyakinan, ibadah, akhlak, muamalah, maupun tatanan kehidupan lainnya, dengan cabang-cabang yang bermacammacam, tujuannya untuk mewujudkan kebahagian dunia dan akhirat (Qattan, 1976: 10).

Dalam perkembangannya, antara syariah dan fikih seringkali dipahami secara tumpang tindih, bahwa antara keduanya tidak ada perbedaan sama sekali. Syariah dan fikih dianggap sebagai dua entitas yang sama, padahal antara keduanya sangat berbeda. Jamal sangat mengkritisi pandangan yang demikian. Menurut Jamal, syariah bukan produk hukum seperti yang selama ini banyak dipahami oleh sebagian orang. Syariah merupakan prinsip dan dasar bagi pengaturan kehidupan manusia dalam pelbagai dimensinya, dengan keadilan sebagai landasan utamanya (al-Banna, 1995: 39). Berdasarkan hal itu, dalam pandangan Jamal, yang dapat disebut syariah hanyalah keputusan hukum yang di dalamnya memuat prinsip keadilan.

Penulis melihat, alasan mengapa Jamal membahas tiga istilah ini tidak lain untuk memposisikan secara benar posisi dan makna ketiga istilah tersebut. Kekeliuran memposisikan ketiga istilah tersebut akan sangat berbahaya, terlebih apabila memposisikan fikih sebagai dimensi yang sama dengan syariah. Padahal, antara fikih dan syariah terdapat perbedaan yang sangat signifikan. Fikih berasal dari pemikiran manusia yang bersifat nisbi, sedang syariah bersumber dari Tuhan yang absolut. Pun demikian, membedakan antara ketiganya sangat penting dalam kerangka proses pembaruan terhadap fikih yang sudah ada. Gampangnya, yang diperbarui adalah fikih sebagai hasil kreativitas pemikiran manusia, dan bukan syariah yang bersumber dari Tuhan yang Maha Benar.

Selain itu, Jamal juga membahas persoalan ijtihad. Secara sederhana, ijtihad dapat diartikan sebagai mengerahkan semua kemampuan untuk memperoleh jawaban hukum 
yang belum ada jawabannya dalam naşh (al-'Umari, 1986: 25). Dalam Islam, ijtihad merupakan aktivitas fundamental yang harus ada sepanjangan zaman. Bahkan, aktivitas ijtihad mendapat legitimasi langsung dari Nabi melalui sahabat Muadz ibn Jabal.

Namun demikian, Jamal mengomentari secara kritis keberadaan ijtihad dalam Islam yang saat ini memang cenderung dianggap sebagai sebuah aktivitas yang sakral, atau dalam istilah lain pintunya dianggap sudah tertutup. Jamal menggunakan bahasa yang agak keras dalam mengomentari persoalan ijtihad, yakni al-Ijtihād hādza al-Ma'lum al-Majhül, atau ijtihad itu sesuatu yang sangat jelas, tapi tidak dikenal (al-Banna, 1995: 45).

Ijtihad disebut jelas karena memang Islam mengenalnya dan pernah dipraktikkan oleh intelektual Islam mulai generasi awal hingga pertengahan. Ijtihad disebut tidak dikenal sebab pada kenyataannya, ijtihad hanya diposisikan sebagai aktivitas elit yang hanya boleh dilakukan oleh orang-orang tertentu saja. Sehingga tidak heran, untuk menjadi mujtahid, terdapat banyak syarat yang harus dipenuhi (Khallaf, 1996: 203-206). Karena syarat yang sangat berat, akhirnya ijtihad menjadi aktivitas yang hanya dipelajari secara teoritis, tapi tidak disarankan untuk diterapkan secara praktis.

Kenyataan demikian yang oleh Jamal dikomentari secara kritis. Adanya doktrin dalam hukum Islam bahwa tidak boleh berijtihad untuk persoalan yang sudah dibahas dalam nash (là ijtihäd ma’a al-Nas) juga turut menjadi obyek yang dikritisi Jamal (al-Banna, 1995: 46-47). Doktrin tersebut mengisyaratkan bahwa dalam proses ijtihad harus terikat pada bunyi teks. Dalam mekanisme Qiyas misalnya. Unsur terpenting dalam Qiyas, illat, hanya diposisikan sebagai indikator semata, dan bukan sebagai unsur yang menentukan hukum (al-Banna, 1995: 48). Gampangnya, meski mencoba keluar dari ikatan teks, namun pada hakikatnya tetap tunduk pada bunyi teks.

Jamal memberi tawaran agar ijtihad tidak sekedar menjadi aktivitas elitis yang tunduk dan terikat pada bunyi teks semata. Ijtihad, menurut Jamal, harus diposisikan sebagai faktor yang melahirkan (munsyi) hukum, dan bukan hanya sebagai penjelas (muģhir) saja (al-Banna, 1995: 49). Ketika diposisikan sebagai munsyi', maka posisi ijtihad akan semakin penting, dan peran akal di dalamnya juga akan semakin penting.

Sebenarnya, persoalan akal dan wahyu merupakan diskusi lama yang tidak pernah selesai untuk didiskusikan. Dalam proses ijtihad, akal merupakan salah satu instrumen penting. 
ljtihad: Jurnal Wacana Hukum Islam dan Kemanusiaan, Volume 19, No. 1, Juni 2019: 1-25

Perdebatan yang selalu timbul adalah, seberapa besar porsi akal dalam proses ijtihad tersebut, apakah hanya sekedar pelengkap, atau akal dapat mengalahkan ketentuan yang adalah teks? Dalam konteks ini, Jamal berada dalam posisi bahwa akal dapat mengalahkan ketentuan dalam teks, sejauh ketentuan dalam teks tersebut tidak relevan dengan kebutuhan zaman. Apa yang dipahami Jamal sebenarnya bukanlah hal baru dalam pemikiran hukum Islam. Lebih jauh, Najmuddin al-Tufi merumuskan teori ri'ayah al-Mạ̦laḥah yang pada intinya mengunggulkan kemaslahatan (akal) atas ketentuan teks, dengan mekanisme takhsi.s. dan tabyin (al-Tufi, 1998: 277).

\section{Produk ijtihad Jamal al-Banna tentang perempuan}

Sebagai seorang intelektual besar, Jamal tidak hanya melahirkan teori dan metodologi, namun juga menghasilkan produk pemikiran (ijtihad), termasuk dalam bidang hukum Islam. Setelah menulis tentang landasan fikih baru, Jamal kemudian menghasilkan sebuah karya yang di dalamnya berisi produk pemikiran tentang perempuan. Dalam karya tersebut, Jamal menawarkan produk ijtihad baru tentang perempuan yang berbeda dengan hasil ijtihad klasik. Di antara produk ijtihad baru Jamal adalah sebagai berikut:

Pertama, definisi perkawinan. Sejalan dengan feminis pada umumnya, Jamal turut mengkritik definisi perkawinan yang dirumuskan dalam literatur fikih klasik. Dalam literatur fikih klasik, perkawinan didefinisikan sebagai akad yang berorientasi pada kebolehan hubungan biologis an sich (Zuhaili, 1985 VII: 29). Padahal, di dalam Al-Qur'an, perkawinan tidak semata-mata bertujuan untuk hal biologis saja, tapi juga untuk mewujudkan ketenangan. Pemikiran ini senada dengan yang disampaikan Syahrur, bahwa dalam perkawinan, orientasi seksualnya hanya $2 \%$ saja, sedang sisanya lebih menyangkut kehidupan sebagai suami isteri (Syahrur, 2000: 310).

Dalam Islam, perkawinan diposisikan sebagai instrumen membangun dan melestarikan peradaban. Memang tidak dapat dipungkiri bahwa aspek seksual juga menjadi salah satu tujuan. Namun perlu dipahami bahwa aspek seksual bukanlah satu-satunya tujuan. Sebagai instrumen membangun peradaban, perkawinan tidak hanya berisi hubungan biologis, namun banyak hal lain seperti relasi suami-isteri dan pola asuh anak. Perkawinan melahirkan hak dan kewajiban yang dibangun di atas prinsip relasional, dan bukan antara yang menguasai 
dan yang dikuasai.

Definisi perkawinan yang diajukan Jamal di atas bertujuan untuk mengkritik definisi dan pemahaman yang dipegang sebagian masyarakat yang menganggap bahwa perkawinan dalam Islam, hanya difungsikan sebagai transaksi yang bertujuan menghalalkan hubungan seksual saja. Terlalu naif apabila perkawinan yang begitu mulia hanya dianggap sebagai alat untuk melegalisasi kebutuhan biologis. Yang lebih penting, perkawinan dalam Islam, bertujuan untuk mewujudkan tiga hal: sakinah, mawaddah, dan rahmah.

Kedua, soal saksi, wali, dan mahar dalam perkawinan. Jamal mempunyai pemikiran yang kontroversial dalam hal ini. Saksi, wali, dan mahar menurut Jamal bukan sesuatu yang primer dalam perkawinan (al-Banna, 1998: 41). Dalam konteks ini, Jamal menyandarkan argumentasinya pada Surat an-Nisa' ayat 25. Ayat tersebut, menurut Jamal, berbicara dalam konteks budak yang harus mendapatkan ijin dari tuannya saat ingin menikah. Sedang untuk perempuan merdeka, tidak ada kewajiban bagi mereka untuk meminta izin kepada walinya. Apa yang dirumuskan Jamal sangat berbeda dengan apa yang dirumuskan oleh ahli fikih (Khallaf, 1990: 26).

Ketiga, relasi suami-isteri. Dalam diskursus hukum keluarga Islam klasik, pola relasi suami-isteri lebih diperlihatkan sebagai relasi yang 'timpang', di mana suami dianggap sebagai pemimpin yang superior, sedang isteri sebagai pihak yang dipimpin, dianggap inferior. Superioritas laki-laki dapat dilihat dalam pelbagai regulasi yang berlaku dalam fikih klasik, terutama ketika berhubungan dengan hak dan kewajiban suami isteri. Dalam fikih klasik, isteri harus taat kepada suami dalam kondisi apapun, dan tidak boleh keluar rumah tanpa izin suami. Bahkan, untuk melaksanakan puasa sunnah, isteri wajib izin kepada suaminya (Munhanif, 2002: 119).

Pola relasi yang timpang ini memang banyak ditemukan dalam pelbagai literatur fikih klasik yang berbicara tentang relasi suami-isteri. Jamal mempunyai pandangan yang berbeda perihal relasi suami-isteri. Relasi suami-isteri, menurut Jamal, bukan relasi saling menguasai, akan tetapi harus saling melengkapi. Relasi saling melengkapi berarti tidak memposisikan satu pihak lebih superior dari pihak lain. Dengan pola relasi ini, tugas domestik dalam keluarga, bukan semata-mata menjadi kewajiban isteri saja, laki-laki juga mempunyai peran di dalamnya. 
Dalam konteks ini, Jamal tetap sepakat bahwa dalam rumah tangga, laki-laki tetap menjadi pemimpin bagi rumah tangganya. Namun demikian, sebagai seorang pemimpin, tugas lakilaki (suami) adalah memberi perlindungan dan membahagiakan isterinya, dengan pola relasi saling melengkapi. Karena sebagai pemimpin, isteri berkewajiban untuk taat kepada suami sejauh pola relasi yang ada sejalan dengan prinsip kesetaraan dan keadilan. Bagi Jamal, surat an-Nisa' ayat 34, tetap harus dimaknai bahwa laki-laki (ar-Rijä) adalah pemimpin (qawwāmūn). Namun demikian, tugas kepemimpinan tersebut tidak berlaku mutlak, tetapi berhubungan dengan tugas dan kewajiban yang diemban, yakni harus memberi nafkah dan membahagiakan isterinya, sesuai dengan pola relasi saling melengkapi sebagaimana yang sudah dijelaskan di atas (al-Banna, 1998: 51).

Keempat, perempuan dan peran sosial. Dalam diskursus yang berkembang dalam fikih klasik, perempuan hanya diberi ruang untuk berperan dalam ruang privat. Peran-peran publik menjadi wilayah yang terlarang bagi perempuan, terutama dalam wilayah politik. Salah satu contoh adalah dilarangnya perempuan menjadi pemimpin di wilayah publik; menjadi pemimpin negara dengan semua tingkatannya. Dalam doktrin fikih politik misalnya, syarat seseorang yang bisa menjadi pemimpin harus berjenis kelamin laki-laki (al-Dahlawi, 2005: 230).

Biasanya, untuk melegitimasi pendapat tersebut, ahli fikih klasik menyandarkan argumentasinya pada teks Al-Qur'an, surat an-Nisa' ayat 34. Ayat tersebut dipahami secara mutlak, bahwa yang berhak menjadi pemimpin, baik dalam wilayah publik maupun privat, hanya laki-laki saja. Selain disandarkan pada teks Al-Qur'an, ketidakbolehan perempuan menjadi pemimpin biasanya juga disandarkan kepada hadis, lan yufliha qaumun wallau amrabum imra'atan, tidak akan beruntung suatu kaum apabila urusannya dipasrahkan kepada perempuan.

Jamal menolak semua argumentasi di atas. Jamal meyakini bahwa perempuan berhak berperan dalam wilayah apa saja, termasuk publik. Untuk memperkuat argumentasinya, Jamal mengutip surat an-Nisa' ayat 32, "Dan janganlah kamu iri hati terhadap apa-apa yang dikaruniakan Allah kepada sebagian kamu lebih banyak dari sebagin yang lain. (karena) bagi orang laki-laki ada bagian dari apa yang mereka usabakan, dan bagi para wanita ada bagian dari apa yang mereka usahakan, dan mohonlab kepada Allah dari sebagian karunia-Nya. Sesunggubnya Allah Maha 


\section{Mengetahui segala sesuatu."}

Menurut Jamal, ayat ini tidak memerici sektor apa saja yang menjadi bagian perempuan. Atas dasar itu, Jamal meyakini bahwa perempuan dapat berperan dalam sektor apa saja, termasuk dalam wilyah politik. Selain menyandarkan pada teks normatif, Jamal juga mengutip fakta historis bagaimana seorang perempuan dapat mengambil peran dalam wilayah publik, seperti Aisyah yang menjadi pemimpin dalam perang Jamal, Ratu Hasabut dari Mesir, Katrina dari Rusia, dan Elizabeth dari Inggris (al-Banna, 1998: 80, 83).

Argumentasi normatif dan historis yang dikemukakan Jamal sebenarnya untuk menunjukkan bahwa wilayah publik bukan wilayah yang haram bagi perempuan. Dalam wilayah publik, yang menjadi tolok ukur adalah kapabilitas dalam memimpin, dan bukan didasarkan pada jenis kelamin. Sebenarnya, apa yang dikemukakan Jamal sejalan dengan kebijakan yang diberlakukan di pelbagai negara, bahwa setiap orang berhak untuk berpartisipasi dan mengambil dalam wilayah apa saja, asalkan memenuhi syarat yang ditentukan.

Selain dalam persoalan kepemimpinan di wilayah politik, perempuan juga dibatasi dalam persoalan persaksian. Dalam persoalan persaksian, ahli fikih klasik mempertahankan bunyi tekstual surat Al-Baqarah ayat 282, “.......dan persaksikanlah dengan dua orang saksi dari orang-orang lelaki (di antaramu). Jika tak ada dua orang lelaki, maka (boleh) seorang lelaki dan dua orang perempuan dari saksi-saksi yang kamu ridhai, supaya jika seorang lupa maka yang seorang mengingatkannya..." Secara tekstual, ayat tersebut menyatakan bahwa kualitas persaksian perempuan berada di bawah laki-kali.

Pemikiran Jamal dalam konteks ini sejalan dengan pemikiran feminis Muslim lainnya. Asghar Ali Enggineer memahami bahwa surat Al-Baqarah ayat 282 tidak bermaksud mereduksi kualitas kesaksian perempuan menjadi separuh dari laki-laki. Ayat tersebut dilihat konteks historisnya. Untuk menjalankan persaksian secara sempurna, perempuan harus ditemani perempuan lain karena pada saat itu perempuan memang belum punya kemampuan mumpuni (Enggineer, 2003: 101).

Bagi Jamal, teks yang berbicara tentang persaksian di atas harus dipahami untuk tidak membatasi kemampuan perempuan. Apa yang disampaikan Al-Qur'an dalam ayat tersebut adalah bentuk pembebasan (tạ̣rir) dan bukan pembatasan (taqyid). Sebagaimana 
persoalan waris, ayat persaksian merupakan bentuk pengakuan Islam terhadap perempuan yang sebelumnya tidak mendapatkan ruang apa-apa dalam struktur budaya masyarakat Arab sebelum Islam (al-Banna, 1998: 19). Sebagaimana yang sudah maklum, dalam tradisi masyarakat Arab pra Islam, perempuan merupakan entitas marjinal yang tidak mempunyai peran apa-apa, ia tidak berhak mendapat waris bahkan menjadi barang warisan, dan tidak boleh berperan dalam wilayah publik (Umar, 2001: 133-135).

Kelima, persoalan cadar. Cadar termasuk bagian isu yang dikaji dan dikritisi oleh para pemikir Islam kontemporer. Selain Jamal al-Banna, terdapat Qasim Amin dan Muhammad Sa'id al-'Asymawi yang menolak anggapan bahwa cadar merupakan bagian dari doktrin syariah. Qasim Amin meyakini bahwa cadar merupakan produk budaya yang dihasilkan dari pergumulan pelbagai tradisi dalam masyarakat (Imarah, 1989: 329). Senada dengan Amin, Muhammad Sa’id al-'Asymawi juga tidak sepakat apabila cadar dianggap sebagai ajaran agama. Cadar hanyalah budaya dan identitas politik semata (al-'Asymawi, 1995: 20-21). Sementara itu, pakar tafsir asal Indonesia, Quraish Shihab, berpandangan bahwa bentuk pakaian, termasuk cadar, yang dianjurkan oleh sebuah agama tak lain hanyalah bentuk refleksi dari budaya yang berkembang (Shihab, 2004: 39).

Kritik para pemikir Islam kontemporer di atas diajukan untuk menolak anggapan sebagian kalangan yang meyakini bahwa cadar merupakan ajaran inti agama. Memang tidak dapat dipungkiri bahwa ada sebagian kalangan yang memahami bahwa cadar termasuk fardu 'ain bagi perempuan dewasa (al-'Asymawi, 1995: 13). Karena termasuk fardu 'ain, maka perempuan dewasa yang tidak mengenakan cadar akan dihukumi berdosa. Salah satu tokoh yang menganggap bahwa cadar merupakan ajaran syariat adalah Abu A'la al-Maududi (alMaududi, 1964).

Sebagai sebuah pemahaman, baik yang menganggap bahwa cadar merupakan ajaran agama maupun bukan, sama-sama dapat diterima. Persoalannya adalah, seringkali pengusung pemahaman bahwa cadar merupakan bagian dari ajaran agama menyalahkan dan menghukumi perempuan yang tidak bercadar sebagai orang yang melanggar ajaran agama, dan oleh sebab itu layak mendapatkan dosa. Anggapan ekstrim seperti ini yang hendak ditolak oleh pemikir Islam kontemporer di atas dengan mengetengahkan wacana dan pemikiran yang berbeda. 
Selain menganggap bahwa cadar bukan doktrin agama, lebih jauh Jamal mempunyai pemikiran yang berbeda perihal aurat perempuan. Salah satu pemikiran Jamal yang kontroversial perihal aurat perempuan adalah dalam persoalan rambut. Jika dalam diskursus fikih klasik rambut perempuan disebut aurat, maka tidak demikian dalam pandangan Jamal. Surat an-Nur ayat 31, "Dan katakanlah pada perempuan yang beriman, agar mereka menjaga pandangannya, dan memelihara kemaluannya, dan janganlah menampakkan perbiasan (zinah), kecuali yang biasa terlihat..." oleh ahli fikih klasik dijadikan landasan dalam persoalan aurat wanita, oleh Jamal justru diinterpretasi secara berbeda. Yang dimaksud dengan Zinah (perhiasan) yang biasa nampak dalam ayat tersebut bukanlah rambut, wajah, dan telapak tangan, melainkan celak, kutek, dan sebagainya (al-Banna, 1998: 29).

Atas dasar ini, menurut Jamal, istilah al-Hijäb yang ada dalam Al-Qur'an tidak dapat dimaknai sebagai cadar atau jilbab, melainkan harus dimaknai sebagai penghalang/pintu yang menutupi orang yang ada di dalam tenda. Ayat tersebut berhubungan dengan masalah permintaan izin ketika ingin memasuki tenda. Sebagaimana sudah dipahami bahwa pada saat itu, masyarakat Arab terbiasa hidup di tenda yang tidak berpintu. (Jamal al-Banna, 1998: 31).

Dalam persoalan aurat perempuan, sebenarnya tidak hanya Jamal yang mengajukan pemikiran kontroversial. Ada sosok pemikir lain yang pemikirannya tentang aurat perempuan lebih kontroversial daripada Jamal. Sosok tersebut adalah Muhammad Syahrur. Dengan menggunakan teori batas (naz̧ariyah hudūdiyah), Syahrur melihat aurat perempuan dari dua sisi: sisi batas minimal (al-Had al-Adna) dan sisi batas maksimal (al-Had al-A'la). Batas minimal aurat perempuan yang wajib ditutupi adalah belahan-belahan (juyüb) seperti bagian antara dua payudara, bagian bawah ketiak, kemaluan dan pantat (Syahrur, 2007: 247). Sedang batas maksimalnya adalah sesuai dengan batas aurat perempuan yang dikenal dalam pelbagai literatur fikih, yakni semua tubuh kecuali wajah dan telapak tangan.

Keenam, poligami. Dalam kajian hukum keluarga Islam, poligami menjadi persoalan yang selalu menarik untuk diperbincangkan. Secara sederhana, poligami dapat dimaknai sebagai ikatan perkawinan di mana suami menikahi lebih dari satu isteri pada waktu yang sama (Mulia, 2004: 43). Dilihat dari praktinya, poligami bukan khas ajaran Islam, dalam artian praktik tersebut telah banyak ditemukan pada masa lalu. Praktik poligami telah ditemukan 
dan dipraktikkan pada zaman nabi terdahulu dan menjadi tradisi masyarakat sebelum Islam (Al-Atthar, 1976: 76).

Poligami yang ada sebelum Islam bersifat tidak terbatas. Seorang laki-laki dapat menikahi banyak perempuan dengan jumlah yang tidak dibatasi. Kemudian, setelah Islam datang, poligami yang tidak terbatas, akhirnya dibatasi maksimal menjadi empat. Pembatasan yang dilakukan Islam dalam praktik poligami menunjukkan bahwa agama ini memperjuangkan hal-hal progresif, terutama dalam konteks perlindungan terhadap perempuan. Jika pada masa sebelumnya poligami dapat dilakukan seenaknya, setelah Islam datang, selain dibatasi, untuk poligami juga diharuskan memenuhi syarat penting, yaitu harus berlaku adil.

Dalam konteks ini, Jamal memahami bahwa praktik poligami yang dilegalkan Islam bukan bertujuan untuk kepentingan seksual, melainkan untuk perlindungan sosial. Surat an-Nisa' ayat 3 yang selama ini menjadi argumentasi normatif-teologis para pendukung praktik poligami, harus dipahami dengan cara memperhatikan aspek historisnya. Dalam pandangan Jamal, ayat tersebut sebenarnya sama sekali tidak menganjurkan apalagi sampai mewajibkan, melainkan berbicara dalam konteks keadilan bagi janda dan anak yatim (alBanna, 1998: 42).

Keadilan bagi janda dan anak yatim merupakan nilai dasar yang diperjuangan $\mathrm{Al}-$ Qur'an dalam surat an-Nisa' ayat 3 tersebut. Konteks disyariatkannya poligami dalam Islam berangkat dari peristiwa perang Uhud, di mana 70 dari 700 laki-laki gugur meninggalkan isteri dan anak-anak. Atas dasar ini, Islam kemudian menjadikan praktik poligami sebagai cara memberi jaminan dan perlindungan terhadap janda-janda beserta anak yatim yang ditinggalkan.

Jika praktik poligami pada dasarnya adalah untuk memberi jaminan dan perlindungan, maka berpoligami tidak semudah hanya dengan membalikkan telapak tangan. Modal berpoligami tidak cukup hanya berdasarkan keinginan, namun harus mampu memberi perlindungan, yang dalam bahasa Al-Qur'an diistilahkan dengan adil. Dengan demikian, praktik poligami yang oleh sebagian kalangan dianggap sunnah Nabi, merupakan pemikiran yang keliru. Sebab, meski dipraktikkan Nabi, dari sembilan isteri yang Nabi nikahi, hanya Aisyah yang perawan. Sisanya, adalah para janda yang Nabi nikahi untuk kepentingan agama. 
Paradigma fikih baru Jamal al-Banna dan relevansinya terhadap pembaruan ...(Syaiful Bahri)

\section{Ijtihad progresif Jamal al-Banna; dari literal ke substansial}

Hasil ijtihad Jamal al-Banna yang sudah penulis bahas di atas, mempunyai nilai progresivitas yang melampaui produk-produk pemikiran yang terdokumentasi dalam pelbagai literatur fikih klasik. Jika mengikuti tipologi yang ditawarkan Abdullah Saeed, hasil ijtihad Jamal dapat dikategorikan sebagai produk ijtihad progresif. Disebut ijtihad progresif karena Jamal tidak mengabaikan teks dan konteks sebagai landasan berpikirnya, namun juga mempertimbangkan konteks kekinian sebagai landasan membangun pemikiran.

Ciri khas pemikiran progresif dapat dilihat dari metodologi yang digunakan sekaligus pemikiran yang dihasilkan. Metodologi pemikiran progresif berangkat dari kesadaran bahwa teks bukan satu-satunya sumber kebenaran. Teks memang menjadi salah satu instrumen penting dalam berpikir (berijtihad). Karena salah satu, maka tidak semua persoalan harus dijawab menggunakan piranti tekstual, tanpa mempertimbangkan kontekstualitas dan kondisi kekinian. Metode berpikir progresif bukan berarti menganggap teks tidak berguna. Teks tetap dikaji dan dipahami beringkut koteks historisnya, sekaligus ditarik ke masa kini yang berbeda.

Dari beberapa contoh hasil ijtihad yang dilakukan Jamal di atas, terdapat poin menarik terutama dalam hal gagasan progresif yang ditawarkan. Jamal berusaha menghasilkan produk pemikiran yang melampaui bunyi tekstual. Karakteristik pemikirannya berpindah dari literal ke substansial. Keberanian menghasilkan pemikiran yang berbeda dengan yang dipahami mayoritas, hanya dapat dilakukan apabila metodologi yang digunakan tidak lagi terpaku pada teks semata. Sebab, bagaimanapun cakupan teks sudah pasti terbatas. Sedang persoalan, setiap waktu selalu berkembang sesuai dengan perkembangan zaman.

Dalam persolan rambut perempuan misalnya. Terlihat sekali pemikiran yang diajukan Jamal berlawanan dengan ketentuan yang dihasilkan oleh ahli fikih klasik. Jamal tidak lagi berpegang pada ketentuan bunyi tekstual ayat yang selama menjadi dalil ahli fikih klasik. Dengan mengajukan interpretasi yang berbeda, Jamal menganggap bahwa aurat perempuan bukanlah aurat yang wajib ditutupi sebagaimana yang selama ini dipahami. Dalam konteks ini, kondisi kekinian oleh Jamal dijadikan pertimbangan dalam menghasilkan produk pemikiran.

Implikasi sosial dari pemikiran Jamal tentang aurat perempuan adalah dalam hal pemaknaan dan pemakaian istilah al-Hịjäb yang selama ini dipahami sebagai cadar dan atau 
jilbab. Selain itu, pemikiran ini juga memberi alternatif baru dalam memahami fenomena perempuan yang tidak menutup rambutnya. Dalam konteks kekinian, banyak dijumpai perempuan-perempuan muslimah yang memperlihatkan rambutnya. Jika mengikuti pemikiran klasik, dapat dipastikan jika perempuan yang tidak menutup rambut akan dihukumi berdosa karena tidak menjalankan perintah agama, berupa menutup aurat, termasuk menutupi rambut tentunya.

Menutup aurat merupakan suatu keharusan. Tapi, sejauh mana batasan yang harus ditutupi, hal itu sudah masuk dalam ranah penafsiran. Seperti yang ditulis Jamal dalam karya nạ̣wa fiqhin jadid, keharusan yang dihasilkan secara tegas dari naṣh kualitasnya berbeda dengan keharusan yang dihasilkan dari pemikiran manusia. Apa yang ditetapkan secara tegas oleh nash wajib dipatuhi, sedang hasil pemikiran manusia, tidak dapat dipaksakan untuk diberlakukan dan diterima. Jika hasil pemikiran tersebut masih relevan harus dipertahankan. Sebaliknya, bila hasil pemikiran tersebut sudah tidak relevan, maka perlu dilakukan perubahan dan tinjauan ulang.

Dalam kajian hukum Islam, menutup aurat tidak masuk dalam kategori ibadah inti. Dilihat dari teori maslahah dalam hukum Islam, menutup aurat masuk dalam kategori maslahah tersier (tahsiniyah) (Zaidan, 1976: 381). Menurut Jamal, sesuatu yang bukan ibadah inti, maka ketentuannya tidak seketat ketentuan yang diberlakukan dalam ibadah inti. Artinya, pemikiran ahli fikih klasik yang mengharuskan perempuan menutup rambut, masih bisa ditinjau ulang dengan mengajukan pemikiran yang berbeda, disesuaikan dengan kebutuhan zaman. Dari sini dapat dipahami bahwa dalam konteks rambut perempuan, Jamal menerapkan prinsip kebebasan (al-Barä'ah al-Așiyah).

Contoh lain yang menunjukkan bahwa pemikiran Jamal bercorak substansial ketimbang literal adalah dalam persoalan poligami. Jamal memahami poligami tidak tekstual, dalam artian poligami tersebut diperbolehkan dalam semua situasi dan kondisi. Anggapan bahwa poligami dianjurkan ditolak keras oleh Jamal. Substansi poligami, menurut Jamal, bukan untuk memenuhi kepentingan biologis. Lebih dari itu, praktik poligami yang diperbolehkan dalam Islam adalah poligami yang bertujuan untuk memberikan perlindungan terhadap janda-janda dan anak yatim.

Pemikiran Jamal tentang poligami di atas berimplikasi pada status poligami dalam Islam. 
Berdasarkan pemikiran Jamal di atas, poligami adalah sarana (wasilah) dan bukan tujuan (maquasid). Karena sebagai sarana, maka pembolehan poligami tergantung pada tujuan yang ada. Artinya, poligami menjadi boleh apabila praktik tersebut dapat mencapai tujuan yang diinginkan, yakni memberi rasa keadilan kepada janda-janda dan anak yatim. Implikasinya, perempuan yang dapat dipoligami hanyalah perempuan janda yang memerlukan perlindungan. Pemikiran yang sama diajukan oleh Muhammad Syahrur, bahwa perempuan yang dapat dipoligami hanyalah perempuan yang berstatus janda (Syahrur, 2000: 303).

Dari beberapa contoh hasil ijtihad Jamal di atas, penulis melihat bahwa setidaknya ada empat hal yang ingin diperjuangkan Jamal dengan mengeluarkan hasil pemikiran yang kontroversial. Pertama, Jamal ingin menunjukkan bahwa ijtihad bukanlah sesuatu yang tabu dan sakral dalam Islam. Ijtihad justru harus dijadikan sebagai piranti utama yang tetap harus dilaksanakan kapanpun dan di manapun. Hanya dengan ijtihad, persoalan-persoalan baru yang terjadi dapat dicari solusinya.

Kedua, corak ijtihad yang diinginkan dan cocok untuk kondisi kekinian adalah ijtihad progresif yang mempunyai paradigma substansial ketimbang literal. Artinya, dalam corak ini, pemikiran tidak boleh dibatasi oleh bunyi teks semata, namun juga harus melihat konteks historisnya, sekaligus kondisi kekinian yang sedang terjadi. Oleh sebab itu, persoalanpersoalan yang tidak masuk dalam kategori ibadah inti, jika sudah tidak relevan dengan zaman, maka bisa dilakukan pembaruan dan tinjauan ulang.

Ketiga, setiap ketentuan yang dihasilkan dari pemikiran seseorang mempunyai keterbatasan dan konteks masing-masing. Meski pemikiran tersebut lahir dari pergumulan antara seseorang dengan teks suci keagamaan, namun tidak ada jaminan bahwa pemikiran tersebut selalu dijamin kebenarannya. Oleh sebab itu, memposisikan pemikiran seseorang secara proporsional, termasuk pemikiran Jamal tentunya, merupakan cara berpikir yang lebih dekat kepada kebenaran. Bagaimanapun, ketentuan yang ada secara langsung dan pasti di dalam nash, sudah pasti terjamin kebenarannya karena bersumber dari wahyu yang bersifat absolut. Sedang pemikiran manusia, tentu saja kebenarannya bersifat relatif.

Keempat, prinsip kebebasan dan keadilan harus menjadi landasan utama dalam setiap proses ijtihad. Produk pemikiran siapapun yang di dalamnya tidak mempertimbangan aspek kebebasan dan keadilan harus dilakukan tinjauan ulang. Syariat harus dimaknai sebagai 
ljtihad: Jurnal Wacana Hukum Islam dan Kemanusiaan, Volume 19, No. 1, Juni 2019: 1-25

rambu dan aturan yang di dalamnya mengandung prinsip keadilan. Sedang pemikiran manusia tidak selamanya mempertimbangkan hal itu (keadilan). Dengan demikian, setiap rumusan hukum yang di dalamnya mengandung keadilan sudah pasti dapat dikatakan syariat. Dan tidak sebaliknya.

\section{Rekonstruksi peran perempuan dalam hukum keluarga Islam}

Dalam pelbagai literatur fikih klasik yang membahas persoalan hukum keluarga, perempuan cenderung diposisikan sebagai makhluk kelas dua setelah laki-laki. Relasi yang dibangun dalam literatur fikih masih memposisikan laki-laki sebagai ordinat, sedang perempuan sebagai subordinat. Apa yang tertulis dalam literatur fikih klasik merupakan produk pemikiran yang sesuai dengan zamannya. Sebagai produk pemikiran, tentu saja tidak dapat disalahkan begitu saja. Sebab, bagaimanapun, pemikiran merupakan produk zaman yang tidak dapat dilepaskan dari konteks yang sedang terjadi. Sehingga, prinsip yang berlaku adalah, apa yang masih relevan dipertahankan, sedang yang sudah tidak sesuai dilakukan pembaruan dan tinjauan ulang.

Potret perempuan dalam lembaran fikih memang demikian adanya. Nuansa patriarkhi begitu terasa, terutama dalam aturan-aturan yang berhubungan dengan hukum keluarga. Dengan berkembangnya zaman dan permasalahan, perlu dilakukan tinjauan dan pembaruan terhadap beberapa isu perempuan dalam hukum keluarga. Pembaruan tersebut bertujuan untuk meninjau ulang posisi dan peran perempuan dalam hukum keluarga Islam. Harapannya, akan lahir fikih perempuan baru yang lebih egaliter, tidak diskriminatif, memberi hak yang sama, dan relasi yang dibangun bukan relasi saling menguasai, melainkan sebagai partner yang proporsional.

Dalam membangun fikih perempuan baru dalam hukum keluarga, penulis akan meminjam paradigma fikih baru yang digagas Jamal al-Banna. Setidaknya, ada empat isu sentral yang menurut penulis layak untuk diperbarui. Pertama, batas minimal usia perkawinan. Dalam literatur fikih klasik, seseorang disebut dewasa apabila sudah memenuhi dua syarat: berakal dan baligh. Berakal pada dasarnya bersifat abstrak. Sedang baligh bersifat konkret karena dapat dirasakan dengan mimpi basah bagi laki-laki dan keluar darah haid bagi perempuan. Jika seseorang tidak juga merasakan baligh, maka ahli fikih membuat standardisasi 
kedewasaan melalui usia. Laki-laki yang tidak mimpi basah hingga umur 15 tahun, maka ia dianggap dewasa. Sedang bagi perempuan, jika sudah berumur 9 tahun meski belum keluar darah haid, maka ia dianggap dewasa juga.

Batasan umur yang menjadi pemikiran dalam Mazhab Syafiiyah di atas berimplikasi pada status seseorang. Laki-laki yang berumur 15 tahun dan perempuan yang berumur 9 tahun, dengan sendirinya sudah menjadi subyek hukum. Semua yang dilakukan dapat dimintai pertanggung jawaban, baik dalam ranah ibadah maupun muamalah. Atas dasar ini, laki-laki yang berumur 15 tahun dan perempuan yang berumur 9 tahun boleh untuk menikah.

Persoalan batas usia perkawinan memang tidak bersentuhan dengan perempuan semata. Batas minimal yang diatur dalam fikih menyangkut kedua belah pihak, baik laki-laki maupun perempuan. Standar minimal usia perkawinan yang diatur dalam fikih perlu ditinjau ulang. Standar minimal 15 dan 9 tahun hanya cocok diterapkan dalam ranah ibadah. Sementara untuk ranah muamalah, khususnya ranah hukum keluarga, sudah tidak sesuai dengan kondisi dan situasi saat ini.

Rumusan fikih baru harus sejalan dengan tuntutan zaman. Pembaruan dalam standar minimal usia perkawinan tidak hanya menyangkut angka yang perlu ditingkatkan, namun juga persamaan antara usia laki-laki dan perempuan. Selama ini, pembaruan yang ada hanya menyentuh angkanya saja. Sedang standar yang digunakan untuk laki-laki dan perempuan tetap dibedakan. Dalam UU No. 1 Tahun 1974 misalnya, standar minimal usia perkawinan bagi laki-laki adalah 19 tahun, bagi perempuan 16 tahun. Pembedaan angka dalam standar minimal usia perkawinan sebenarnya masih menunjukkan adanya ketimpangan. Bagi lakilaki, usia 19 tahun berarti sudah menyelesaikan wajib belajar 12 tahun. Berbeda dengan perempuan, usia 16 tahun berarti ia belum menyelesaikan pendidikan sebagaimana yang didapatkan laki-laki. Atas dasar ini, usia minimal perkawinan, baik bagi laki-laki dan perempuan harusnya disamakan. Ada dua alternatif pilihan angka usia yang bisa digunakan, yakni harus sama-sama berumur 19 tahun, atau ditingkatkan lagi menjadi 21 tahun.

Kedua, penghapusan hak ijbār bagi wali. Status wali dalam literatur fikih klasik dianggap sebagai sesuatu yang primer. Ada tidaknya wali menentukan sah tidaknya perkawinan. Dalam konteks ini, penulis tetap menganggap bahwa wali merupakan hal yang penting. Berbeda dengan Jamal yang menganggap bahwa wali bukanlah hal yang primer. Oleh 
sebab itu, jika menggunakan pemikiran Jamal, perempuan dewasa yang merdeka berhak menikahkan dirinya sendiri tanpa perlu ada izin dari walinya. Sebenarnya, persoalan wali dalam perkawinan, merupakan wilayah yang di dalamnya masih terjadi perbedaan, termasuk di kalangan fuqahä' sendiri.

Hal penting yang perlu diperbarui dalam masalah wali adalah adanya hak ijbār (memaksa) bagi orang tua terhadap anaknya yang masih perawan. Hak tersebut perlu ditinjau ulang karena berlawanan dengan prinsip kebebasan (al-Barāah al-Asliyah) yang menjadi prinsip dalam Islam. Meski posisi wali sangat penting dalam perkawinan, bukan berarti wali dapat seenaknya memaksa perempuan untuk menikah dengan laki-laki tertentu. Bagaimanapun, perkawinan yang dilakukan dengan paksaan, dengan sendirinya telah mencederai tujuan fundamental dari pernikahan itu sendiri.

Urgensi wali dalam perkawinan, selain memberi restu, adalah memberi pertimbangan dan masukan, bukannya memaksa perempuan untuk menikah dengan laki-laki tertentu. Oleh sebab itu, perempuan yang sudah dewasa, tidak dapat dipaksa oleh siapapun, termasuk orang tuanya sendiri. Atas dasar ini, menghapus hak ijbär yang melekat pada wali merupakan suatu keharusan. Idealnya, relasi antara wali dan perempuan adalah relasi saling melengkapi, dan bukan relasi saling memenangkan ego pribadi.

Ketiga, poligami. Ketentuan poligami yang berlaku di dalam literatur fikih klasik memberi kebebasan kepada laki-laki untuk melakukan poligami tanpa 'harus' meminta izin kepada isteri pertama. Syarat utama yang harus dipenuhi hanyalah harus berbuat adil. Jika laki-laki sudah merasa mampu berbuat adil, maka praktik poligami bisa dilaksanakan. Ketentuan yang ada dalam fikih klasik ini memberi ruang kepada laki-laki untuk 'seenaknya' melakukan poligami. Padahal, dalam Islam, poligami bukan hanya berhubungan dengan persoalan kemampuan mewujudkan keadilan, namun juga perlindungan bagi perempuan.

Pembaruan dalam konteks poligami harus mengarah kepada perlindungan terhadap perempuan. Jika dalam fikih klasik ada kebebasan untuk melakukannya, maka perlu ada rumusan baru, bahwa poligami hanya dapat dilakukan apabila yang menjadi pertimbangan adalah perlindungan bagi perempuan, terutama bagi janda dan anak yatim. Ketentuan kebolehan poligami 'seenaknya' harus diperbarui menjadi kebolehan yang tergantung pada banyak syarat ketat. Poligami harus mewujudkan keadilan dan perlindungan, dan bukan 
menyakiti apalagi menelantarkan.

Dalam praktik poligami, yang perlu diperhatikan adalah kepentingan perempuan. Jangan sampai aturan poligami yang sebenarnya mempunyai tujuan mulia justru membuat perempuan terluka. Maka, rumusan-rumusan progresif tentang poligami dalam fikih tidak hanya berkutat pada unsur memperketat kebolehan beristeri lebih dari satu orang. Lebih jauh, aspek perlindungan, harus menjadi orientasi utama dalam praktik poligami tersebut.

Keempat, talak. Selama ini, ketentuan yang ada dalam pelbagai literatur fikih menganggap bahwa talak merupakan hak prerogatif suami yang dapat diucapkan kapanpun dan di manapun. Ketentuan ini berimplikasi pada posisi perempuan yang sekali lagi selalu menjadi korban. Padahal, akibat hukum dari jatuhnya talak adalah putusnya perkawinan. oleh sebab itu, ketentuan yang memperbolehkan dapat diucapkan kapanpun dan di manapun perlu ditinjau ulang.

Suami memang mempunyai hak untuk memutuskan ikatan perkawinan. Namun, hak tersebut tidak boleh digunakan seenaknya. Ketentuan talak harus diperketat dengan aturan baru bahwa, penjatuhan talak tidak dapat dilakukan kecuali diucapkan di hadapan pengadilan. Aturan ini sejalan dengan ketentuan yang ada dalam Undang-undang perkawinan. Jika antara fikih dan Undang-undang mempunyai ketentuan yang sama, maka masyarakat akan lebih mudah menerima bahwa talak tidak dapat diucapkan seenaknya.

\section{Penutup}

Jamal al-Banna merupakan sosok pemikir Islam kontemporer yang mempunyai gagasan pembaruan dalam hukum Islam yang ia istilahkan dengan fikih baru ( fiqh jadid). Fikih baru yang digagas Jamal dapat dijadikan metodologi alternatif dalam menjawab persoalan baru maupun persoalan lama yang perlu dilakukan pembaruan dan tinjauan ulang. Secara metodologis, fikih baru yang digagas Jamal berangkat dari kesadaran bahwa ijtihad bukanlah area terlarang yang 'haram' untuk dilakukan. Ijtihad merupakan instrumen penting dalam Islam yang harus dikembalikan kepada fungsi asalnya, yakni sebagai proses fundamental dalam menjawab persoalan yang perlu dicari solusinya.

Landasan fikih baru yang digagas Jamal berangkat dari prinsip keadilan dan kebebasan (al-Barāah al-Așiyah). Keadilan dan kebebasan harus menjadi landasan dalam setiap proses 
ljtihad: Jurnal Wacana Hukum Islam dan Kemanusiaan, Volume 19, No. 1, Juni 2019: 1-25

ijtihad. Sebab, menurut Jamal, yang dapat disebut syariat hanyalah ketentuan yang di dalamnya mengandung prinsip keadilan dan kebebasan. Dengan menggunakah fikih baru yang digagasnya, Jamal kemudian merombak beberapa ketentuan yang terdapat dalam pelbagai literatur fikih klasik, khususnya tema-tema yang berhubungan dengan perempuan.

Dengan menggunakan paradigma fikih baru Jamal, terdapat beberapa isu tentang peran perempuan dalam hukum keluarga Islam (fiqh al-Munäkaḥāt) yang bisa diperbarui dan ditinjau ulang. Peran perempuan yang dalam ketentuan literatur fikih klasik cenderung dinomorduakan, setelah diperbarui dan ditinjau ulang, perannya menjadi setara dan proporsional. Ada empat isu krusial yang penulis tinjau menggunakan fikih baru Jalam alBanna: usia minimal perkawinan, hak ijbār bagi wali, poligami, dan talak.

\section{Daftar pustaka}

Al-Asymawi, Muhammad Sa’id. Haqiqah al-Ḥijäb wa Hüjuiyah al-Hadis. Kairo: Maktabah Madbuli, 1995.

Auda, Jasser. Membumikan Hukum Islam melalui Maqasid Syariah, terj. Rosidin dan Ali 'Abd El-Mun'im. Bandung: Mizan, 2015.

Audah, Abdul Qadir. Metodologi Pengajaran Agama Islam, terj. H.A. Mustofa. Jakarta: Rineka Cipta, 2008.

Al-Bugha, Mustafa Dib. Asar al-Adillah al-Mukhtalaf 'Alaiha fi al-Fqh al-Islämi. Damaskus: Dar al-Imam al-Bukhari, tt.

Al-Dahlawi, Syah Waliyullah. Hujjatullah al-Bäligah. Beirut: Dar al-Jail, 2005.

Enggineer, Asghar Ali. Pembebasan Perempuan, terj. Agus Nuryatno. Yogyakarta: LKiS, 2003. Imarah, Muhammad. Qäsim Amin wa Taḥir al-Mar'ah. Kairo: Dar al-Syuruq, 1989.

Khallaf, Abdul Wahhab. Aḅkām al-A ḥwäl al-Syakhsiyah fi Syariah al-Islämiyah. Kuwait: Dar al-Qalam, 1990.

Ilm Usül al-Fiqh. Kairo: Darul Fikr al-Arabi, 1996.

Mahmud Tamhaz, Abdul Hamid. Al-Fiqh al-Ḥanafi fi Șaubihi al-Jadid. Damaskus: Dar alQalam, 2009.

Meuleman, Johan Henrik. Membaca Al-Qur'an bersama Mohammed Arkoun. Yogyakarta: LKiS, 2012. 
Paradigma fikih baru Jamal al-Banna dan relevansinya terhadap pembaruan ...(Syaiful Bahri)

Al-Maududi, Abu A’la. Al-Ḥijäb. Damaskus: Dar al-Fikr, 1964.

Muhammad Ali, Muhammad Abdul 'Ati. Al-Maqāsid al-Syari'ah wa Asaruhā fi al-Fiqh alIslämi. Kairo: Dar al-Hadis, 2007.

Mulia, Siti Musdah. Islam Menggungat Poligami. Jakarta: PT Gramedia Pustaka Utama, 2004.

Munhanif, Ali. Perempuan dalam Literatur Islam Klasik. Jakarta: Gramedia Pustaka, 2002.

Nasution, Harun. Ensiklopedia Islam Indonesia. Jakarta: Djembatan, 1992.

Al-Qattan, Manna' Khalil. Al-Tasyri’ wa al-Fiqh fi al-Isläm. Kairo: Maktabah Wahibah, 1976.

Ar-Raisuni, Ahmad. Figh Șaurah Muräjä'ätfi al-Figh al-Siyāsi al-Islämi. Kairo: Dar al-Kalimah, 2013.

Shihab, M. Quraish. Jilbab: Pakain Wanita Muslimah. Jakarta: Lentera, 2004.

Syahrur, Muhammad. Nahwwa Usūl al-Jadidah li al-Fiqh al-Islämi: Fiqh al-Mar'ah. Damaskus: Dar al-Ahali li al-Tiba'ah wa al-Nasyr, 2000.

Prinsip dan Dasar Hermeneutika Hukum Islam Kontemporer.Yogyakarta: Elsaq Press, 2007.

Syarifuddin, Amir. Hukum Perkawinan Islam di Indonesia. Jakarta : Kencana, 2006.

Taimiyah, Ibnu. Kutub wa Rasaìl wa Fatwā. Riyad: Maktabah Ibn Taimiyah, tt.

Al-Tufi, Najumdin. Kitāb al-Ta'yin fi Syarh al-Arbain. Beirut: Muassah Rayyan, 1998.

Al-'Umari, Nadia Syarif. Al-Ijtihād fi al- Isläm. Beirut: Muassasah Risalah, 1986.

Umar, Nasaruddin. Argumentasi Kesetaraan Jender dalam Al-Qur'an. Jakarta: Paramadina, 2001. Zuhaili, Wahbah. Al-Fiqh al-Islāmi wa Adillatubu. Damaskus: Dar al-Fikr, 1985. 
